\title{
THE CRISIS OF CONSTITUTIONAL LITERALISM IN AUSTRALIA
}

\author{
GREG CRAVEN*
}

\begin{abstract}
The article acts as an introduction to current Australian debates concerning constitutional interpretation. Since the 1920s, the dominant interpretive scheme has been "literalism." Under this theory, the High Court has concerned itself with finding meaning exclusively within the written text. This highly technical approach to constitutional interpretation has masked a political agenda of centralising power into the hands of the federal government. For this and other reasons, literalism is losing favour in Australia and several other interpretive strategies are being advanced. The article concludes by summarising the challengers to literalism, analyzing their merits and weaknesses, and suggesting a synthesis.
\end{abstract}

Le présent article sert à présenter les débats australiens actuels en matière d'interprétation constitutionnelle. Depuis les années 1920, la théorie dominante a été celle du "littéralisme", c'est-à-dire l'interprétation littérale et grammaticale de la Constitution. Régie par cette théorie, la Cour haute $s^{\prime} e s t$ attachée à ne trouver de signification qui à l'intérieur du texte écrit. Cette approche hautement rechnique masque un programme politique qui veille à centraliser le pouvoir entre les mains du gouvernement fédéral. Pour cette raison, entre autres. l'interprétation littérale est en perte de vitesse en Australie, et plusieurs autres stratégies sont actuellement proposées. L'article conchut en les résumant, en analysant leurs mérites et leurs faiblesses, et en suggérant qu'on adopte une synthèse.

\section{TABLE OF CONTENTS}

I. INTRODUCTION .................... 492

II. THE COURSE OF LITERALISM $\ldots \ldots \ldots \ldots \ldots \ldots \ldots \ldots 493$

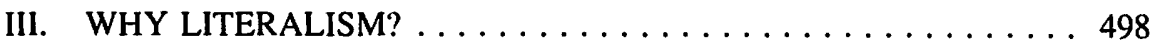

IV. THE FALL FROM GRACE OF LITERALISM $\ldots \ldots \ldots \ldots \ldots 502$

V. THE CHALLENGES TO LITERALISM . . . . . . . . . . . . . 507

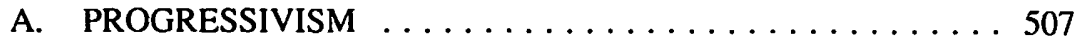

B. INTENTIONALISM $\ldots \ldots \ldots \ldots \ldots \ldots \ldots \ldots \ldots \ldots$

VI. IMPLICATIONS OF PROGRESSIVISM AND

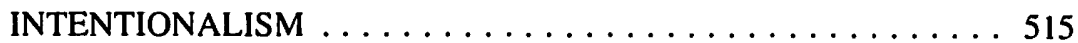

VII. THE FUTURE - IS THERE A WAY FORWARD? . . . . . . . . 519

\section{INTRODUCTION}

Since its great decision in the Engineers' case' in 1920, literalism has been the Australian High Court's enunciated methodology of constitutional interpretation. Applying a literalist approach, the Court has had a profound effect upon Australian society in presiding over the gradual but inexorable expansion of the powers of the Commonwealth at the expense of those of the States. Moreover, notwithstanding certain widely acknowledged theoretical difficulties, and the necessity for occasional modification around

B.A., LL.M. (Melb.); Senior Lecturer in Law, University of Melbourne.

Amalgamated Society of Engineers v. Adelaide Steamship Co. Lad. (1920), 28 C.L.R. 129. 
the edges of the doctrine, literalism has generally been accepted and defended by Australian judges and academic lawyers alike. Today, however, the constitutional literalism of the High Court is an orthodoxy under challenge, and one which shows increasing signs of buckling under both external and internal pressures. This is not to say that the chapter opened by Engineers is now closed: literalism remains the cornerstone of constitutional interpretation in Australia. But as we approach the centenary of Federation, literalism undeniably looks more vulnerable than at any other stage in its long history.

This article seeks to trace the rise and decline of literalism, and to consider the directions which might be taken by Australian constitutional interpretation after literalism's fall. The paper will, first, outline the nature of literalism and its course in the interpretation of the Australian Constitution. Secondly, it will endeavour to isolate the reasons, both 'legal' and 'political', which have prompted the High Court to attach itself to an interpretative methodology of literalism. Next, the wide variety of contemporary factors and influences which are operating upon the High Court so as to weaken its once strong allegiance to literalism will be identified and examined. The article will go on to examine the emergence of the two most obvious current challenges to literalism, for convenience referred to as 'progressivism' and 'intentionalism'. The implications held by the High Court's substantial desertion of literalism in favour of either of these other approaches to constitutional interpretation will be isolated and considered. A modest attempt will also be made to outline what the author believes to be an appropriate alternative interpretative methodology for use within post-literalist Australian constitutional practice.

\section{THE COURSE OF LITERALISM}

To talk of 'literalism' gives rise to the regrettable necessity of defining that phenomenon. ${ }^{2}$ For present purposes, 'literalism' (or at least Australian literalism) comprises the view that the Constitution is to be interpreted by reading its words according to their natural sense and in documentary context, and then giving to them their full effect. ${ }^{3}$ At least four key features of 'literalism' thus defined may readily be discerned.

First, literalism clearly assumes that the words of the Constitution will (at least as a general rule) have a determinate meaning which may be ascertained with reasonable

2. See e.g. the debate comprised in: B. Galligan, The Politics of the High Court (St. Lucia, New York: University of Queensland Press, 1987); J. Goldsworthy, "Realism about the High Court" (1989) 18 Federal Law Review' 27; B. Galligan, "Realistic Realism and the High Court's Role" (1989) 18 Federal Law Review 40; J. Goldsworthy, "Reply to Galligan" (1989) 18 Federal Law Review 51. See also P. Hanks, Constitutional Law in Australia (Sydney: Butterworths, 1990) 21-26.

3. E.g. Amalgamated Society of Engineers, supra, note 1 at 142, 148-149. P.H. Lane, The Australian Federal System. 2nd ed. (Sydney: Law Book Co., 1979) at 1177; Galligan, Politics of the High Court supra, note 2 at 258; G. Sawer, Australian Federalism in the Courts (Carlton, Victoria: Melbourne, University Press, 1967) 96. 
readiness. ${ }^{4}$ Secondly, and following from this, there can (again as a general rule) be no occasion to search for meaning outside the text by reference to notions of grand constitutional theme or design, and only a very limited occasion to do so by reference to such humbler considerations as the wider history of the provision concerned. ${ }^{5}$ Thirdly, the policy results of a particular interpretation are, as such, irrelevant. Finally, despite its intrinsic textualism, Australian literalism itself does depend ultimately upon one wider canon of constitutional construction, namely, the necessity of finding the author's intent. This flows from the fact that the implicit basis of literalism's exclusive reliance upon the text is that it is the text which is the best and most reliable means of discerning the intent. $^{6}$

It should be noted that the High Court did not invent literalism. When Sir Isaac Isaacs in the Engineers' case set the Court on its literalist course, he was able to support his position by reference to well-established themes of British statutory interpretation. Indeed, the central justification for constitutional literalism running throughout Engineers is that the Constitution is a British statute, and as such is to be interpreted like other British statutes, that is, literally. ${ }^{7}$ Consistent with what was said above concerning the nature of literalism, the English cases relied upon in Engineers do implicitly recognize that literalism is not an end in itself, but merely instrumental: reliance upon the text is required simply because the words are the best means of arriving at the intent.

Probably one of the more striking features of the High Court's adherence to literalism is that it emerged only after a long period of decidedly non-literalist interpretation by the original Justices, Griffith, Barton and O'Connor. They took the view that constitutional provisions could be understood and applied only within the context of wider considerations, which together went to comprise what might reasonably be referred to as 'the spirit of the Constitution'. The basic effect of this approach was that the written Constitution was interpreted as being subject to a number of fundamental but unexpressed constitutional principles, ${ }^{9}$ drawn from the nature (rather than the text) of the Constitution as an embodiment of a co-ordinate and strongly decentralized federalism. ${ }^{10}$ The most important of these principles was the so-called doctrine of 'reserved powers', probably

6.

(2)

Sawer, ibid. at 95.

E.g, Amalgamated Society of Engineers, supra, note 1 at 129, 142, 148.

D. Dawson, "Intention and the Constitution - Whose Intent?" (1990) 6 Australian Bar Review 93 at

94 and 100 . One might also seck to defend textual supremacy on the grounds of certainty, and the necessity that the law be readily ascertainable, rather than hidden in obscure sources of subjective intent. However, in the final analysis, such arguments must be subordinate to that turning on intention: unless textualism is ultimately traceable to authors' intent, it becomes an arbitrary and essentially accidental interpretative process, and as such logically indefensible.

7. Amalgamated Society of Engineers, supra, note 1 at 148-50.

8. See the joint judgment ibid. at 150-52.

9. For standard descriptions of the constitutional style of the first High Court see e.g. L. Zines, The High Court and the Constitution, 2nd ed. (Sydney: Butterworths, 1987) at 1-15, 341-8; Sawer, supra. note 3 at 124-9; M. Coper, Encounters with the Australian Constitution (North Ryde. N.S.W.: CCH Australia, 1987) at $177-81$. 
best rendered as requiring that the legislative powers of the Commonwealth be interpreted with extreme caution, so as to avoid any corresponding reduction in the powers of the States which would be inconsistent with the Constitution's broader federal vision. "In any event, it is clear that however the constitutional doctrines of the first High Court were expressed, they were in no sense 'literalist', and they worked broadly in favour of the States by limiting the powers of the emergent Commonwealth.

To a significant extent, in fact, the first High Court's constitutional jurisprudence centred on a notion of giving direct and immediate effect to the perceived wider intentions of the Founders, without the absolute necessity of deducing those intentions via the medium of specific constitutional language. In this sense, it was indeed intrinsically antagonistic to most of the precepts of the Court's later literalism. However, in accordance with comments made earlier, it may again be noted that even a strict Engineers literalism and the approach of judges like Griffith and Barton do share one basic assumption: in the final analysis, each acknowledges that at the heart of constitutional interpretation lies a search for the relevant intent.

History, of course, records that in the Engineers case, the forces of literalism gained a decisive victory over their less text-centred opponents, and the precise details of that victory are too well known to bear much repetition. Suffice to say that the jurisprudence of the first High Court was quite overturned, and the Court announced its future adherence to the principle that the Constitution would be interpreted in accordance with 'the natural meaning of the text' and not by reference to '[an] implication drawn from what is called the principle of "necessity," that being itself referable to no more definite standard than the personal opinion of the judge who declares it'. ${ }^{12}$ It is this ringing endorsement of literalism that has ever since been at the heart of the Court's declared approach to constitutional interpretation. Notwithstanding widespread criticism of both the style and the content of the joint judgment in Engineers, ${ }^{13}$ the literalist banner proudly raised by Isaacs is ritually unfurled by the Court on most occasions at which an important federal division of powers case is decided in favour of the Commonwealth. ${ }^{14}$

The immediate practical effect of the Court's conversion to literalism is, of course, clear enough. The old, States-protective doctrines developed by the Griffith Court having been swept away, the specifically expressed, literally interpreted powers of the Commonwealth contained in section 51 were free to bite deeply into areas of State 8 C.L.R. 330.

12. Amalgamated Society of Engineers, supra, note 1 at 141-42, Knox C.J., Isaacs, Higgins, Rich and Starke J.J.

13. See e.g. Zines, supra, note 9 at 10-12; Sir D. Dawson. "The Constitution - Major Overhaul or Simple Tune-Up?" (1984) 14 Melbourne University Law Review 353: Sawer, supra, note 3 at 198-200.

14. Sec e.g. Commonwealth v. Tasmania (1983), 158 C.L.R. 1 at 127-28, Mason J.; 220-21, Brennan J.; Koowarta v. Bielke-Petersen (1982), 153 C.L.R. 168 at 225-29, Mason J. 
residual power. ${ }^{15}$ (Naturally, under a regime of literalism, specifically expressed powers possess an inherent advantage over those expressed in residual terms.) In reality, however, it was the genesis in Engineers of something rather more than a 'straightforward' literalism which so seriously weakened the constitutional positions of the States, and which gave to Australian literalism much of its distinctive flavour. For the primary rule to be derived from Engineers has come to be for most practical purposes not merely that the powers of the Commonwealth are to be interpreted literally, but that they are to be interpreted literally, and as expansively (i.e. as favourably to a finding of Commonwealth legislative competence) as possible. In other words, a 'literal' interpretation of a provision conferring power upon the Commonwealth (usually one of the placita of section 51) tends (far from self-evidently) to be equated with the interpretive choice of a construction that is most sympathetic to the expansion of Commonwealth power. ${ }^{16}$

As it happens, the 'expansive' interpretation component of this equation has a longer history in Australia's constitutional jurisprudence than its purely literalist companion. It derives ultimately from such dicta as that of O'Connor J. in Jumbunna Coal Mine No Liability v. Victoria Coal Miners' Association, ${ }^{17}$ to the effect that the terms of a written Constitution should be interpreted broadly, rather than narrowly. But the effect of Engineers and its successor cases has been basically to absorb the rule in Jumbunna within the fabric of literalism, so that the rule has for most intents become not 'Interpret the Constitution broadly and non-technically', but something much closer to 'Take a Commonwealth legislative power, formulate the widest literal interpretation possible, and then apply it, regardless of context or any other factors which might suggest that the result was not the one intended'. ${ }^{18}$ This whole approach will shortly be examined further, ${ }^{19}$ but it is worth noting at this stage that it is not particularly apt to describe it merely as 'literalism.' It is more properly characterized as a particular form of 'ultra-literalism'. By 'ultra-literalism' I mean an interpretative methodology which not merely asserts the conclusiveness of the text over other considerations, but does so with a single-minded disregard of surrounding context and circumstance in considering what the text itself is to mean.

15. Under the Australian Constitution, most of the Commonwealth's powers are specifically enumerated in section 51, while the States receive a residuary power under section 107. For examples of Commonwealth expansionism see Pirrie v. McFarlane (1925), 36 C.L.R. 170; South Australia v. Commonwealth (First Uniform Tax case) (1942), 65 C.L.R. 373; Fairfax v. Federal Commissioner of Taxation (1965), 114 C.L.R. 1.

See e.g. Commonwealth, supra, note 4 at 127-29, Mason J. Although a comparatively limited form of expansive interpretation, restrained by the operation of such doctrines as reserved powers, did exist under the First High Court.

(1908), 6 C.L.R. 309 at 367-68.

See e.g. Dawson, supra, note 6 at 356.

Infra, text accompanying notes 28-35; and see G. Evans, "The High Court and the Constitution" in

D. Hambly and J. Goldring. Australian Lawyers and Social Change (Sydney: Law Book Co.. 1976) 13 at $37-41$. 
The majority of important division of powers cases will at some point contain an important reference to this 'expansive' (i.e. ultra-literalist) canon of construction. Thus, in the Dams case, Mason C.J stated that:

In the ultimate analysis the comprehensive legal answer to the general considerations which Tasmania invokes to sustain its approach to the interpretation of the constitutional power is that a grant of power in $\mathbf{s .} 51$ is to be interpreted with all the generality that the words used allow. ${ }^{20}$

Similar examples of such an approach may be seen in the judgments of those justices favouring a wide interpretation of the external affairs power in Koowarta v. BielkePetersen, ${ }^{21}$ and of the corporations power in Actors and Announcers Equity Association v. Fontana Films Pty. Lid. ${ }^{22}$ In short, the ultra-literalism which stems ultimately from the joint judgment in Engineers has not been merely alive and well, but positively flourishing on the High Court during recent years. It is precisely this approach to constitutional interpretation that inspired the lament of Sir Daryl Dawson:

There is a notion to be found in the cases, for which the Engineers case is called in aid, that Commonwealth legislative powers are to be given the widest interpretation which the language bestowing them will bear, uninhibited by the context of the document in which they appear and the nature of the compact which it contains. ${ }^{23}$

Of course, the High Court has not in the years since Engineers walked unswervingly down a literalist path. The simple reason for this backsliding is, as Sir Owen Dixon put it, that no document can be interpreted absolutely literally and without regard to implications, and this is particularly true of a written constitution, necessarily framed in broad terms providing for an entire system of government. ${ }^{24}$ Thus, within twenty years of Engineers, States-protective implications were again being read into the Constitution on the basis of the nature of Australian federalism. However, they are only a dim reflection of the past glories of the doctrine of reserved powers. ${ }^{25}$

Another concession in favour of the use of implications, this time operating to the benefit of the Commonwealth, is the emerging concept of the implied power from nationhood. ${ }^{26}$ Nevertheless, it would be wrong to see these comparatively minor inroads as compromising the Court's essential commitment to a literalist interpretative technique, particularly in the context of the division of powers. On the contrary, the Court has constantly re-affirmed and demonstrated its basic support for the literalism of Engineers,

20.

21.

22.

23.

24.

25.

26.

Commonwealth, supra, note 14 at 127.

Section 51 (xxix); (1982), 153 C.L.R. 168.

Section 51 (xx); (1981), 50 C.L.R. 169, and see especially the judgment of Mason J. at 206-08.

Dawson, supra, note 6 at 354 and 356.

Melbourne Corporation v. Commonwealth (1947), 74 C.L.R. 31 at 81-82.

See e.g. South Australia, supra, note 15; Commonwealih, supra, note 14 . See also Street v. Queensland Bar Association (1989), 63 A.L.J.R. 715.

See e.g. Commonwealth, ibid.; see also C. Saunders, "The National Implied Power and Implied

Restraints on Commonwealth Power" (1984) 14 Federal Law Review 267. 
and this is most clearly evident in the series of cases decided in the late seventies and early eighties expanding Commonwealth legislative power in the fields of external affairs. ${ }^{27}$ Accordingly, notwithstanding some significant modifications at the periphery, it is fair to say that the general literalist hegemony established in Engineers continues to the present day.

Nevertheless, one of the main points of this article is to suggest that the influence of Engineers on Australian constitutional methodology is slipping, and to explain why this might be so. The exact nature of the alternative interpretative approaches threatening literalism will be fully outlined later in this paper, though it is appropriate at this point to describe them in broad terms.

The first alternative interpretive approach may be labelled 'progressivism'. Briefly, progressivism begins by stressing the ambiguity of constitutional language, and denying its self-sufficiency as a means of resolving constitutional disputes. It goes on to posit that the deciding factor in constitutional interpretation will be whether a particular construction answers the needs and advances the aspirations of modern Australian society. While the text is not discarded, it is dethroned: to one committed to progressivism, a simple and unelaborated literalism is grotesque.

The other threat to literalism is what may loosely be referred to as 'intentionalism'. Intentionalism essentially posits that the absolute and overriding duty of a constitutional court is to give effect to the intentions of those who framed the constitution. It follows from this that the text cannot, at least in a literalist sense, be supreme: the crucial thing is the intent, so other sources which reflect this intent are relevant. Once again, the text is not rejected, but it is not dispositive. Before considering these challenges to literalism, it is appropriate to isolate the factors underlying both its rise to orthodoxy, and the beginning of its fall.

\section{WHY LITERALISM?}

The essential question in this context is why the High Court adopted literalism in the first place, and why it has continued to adhere to it for so long. The picture here is somewhat confused. Clearly enough, some judges (and other authorities), would defend literalism on purely 'legal' grounds, arguing that it is an approach to constitutional interpretation mandated by law. Others might frankly admit that whatever literalism lacks in legal logic, it more than makes up through its facility as a means of transferring power from the States to the Commonwealth, something which is (in their view) a highly

Koowarta. supra, note 14 at 226-28, Mason J.; Commonwealth, supra, note 14 at 126-29, Mason J. and 168-70, Murphy J. and 220-21, Brennan J.; Richardson v. Forestry Commission (1988), 164 C.L.R. 261 at 307 per Deane J. See also "The Seventieth Anniversary of the Engineers Case Celebrated" (1990) 64 Australian Law Journal 755. 
desirable end. The true attractions of literalism to the High Court have tended to lie somewhere in between these two positions. ${ }^{28}$

On an institutional level, it would be profoundly naive not to recognize that a major motive in the Court's continued adherence to literalism has been its positive desire to ensure that the federal balance of power is tilted firmly in favour of the Commonwealth. This has been recognized, tacitly or explicitly, by virtually every knowledgeable commentator. ${ }^{29}$ In short, literalism has been an instrument of Commonwealth power ever since Engineers, and its usefulness in this regard underlies both its adoption and continuance.

In one sense, this does not take anyone much further in trying to understand the attraction of literalism for the Court. Certainly, it reveals that at least part of that attraction is 'political' (in the sense that it is based on an opinion as to the political desirability of a particular constitutional result), but it necessarily begs the question of why the Court has been so enamoured of the extension of central power. This is a difficult question, perhaps better answered by a historian (or even a sociologist or psychologist) than a lawyer, but a few brief points may be made.

To begin at the beginning, to judges like Isaacs, any movement towards the centralization of power (and thereby, incrementally, towards unification) seemed like national progress. There is an historic, and even a personal dimension here. The greatest political problems faced by Australians before Federation had been general disunity and numerous specific petty colonial squabbles. It was the great work of Federation (and people like Isaacs) to remedy this situation: Australia was to be a great new nation, with a similarly great destiny. ${ }^{30}$ It is only a short step from this sort of nationalism, a nationalism that not unreasonably sees division and difference in all their forms as its natural enemies, to the conclusion that anything which stresses a single, central, united power over the disparate powers of the States is an objective constitutional good. ${ }^{31}$ The first thirty years following federation - exposing the new Commonwealth as it did to the stresses of war and economic depression - can only have served to strengthen this conviction in minds already favourable to the expansion of central power. Similar points can be made, over a longer span of time, in relation to such nationally traumatic events as the Second World War, Post-War Reconstruction, the oil crisis of the seventies, and the recession of the nineties.

28.

Galligan, "Realistic Realism," supra, note 2 at 44-47; Goldsworthy, "Realism About the High Court," supra, note 2 at 35-36.

29. See e.g. Sawer, supra, note 3 at 129-32 and 196-208; Zines, supra, note 9 at 343; Coper, supra, note 9 at 193-8.

30. This nationalistic vision runs through the joint judgment in the Engineers case (see especially at 15152), and see also Isaacs' speech to the Convention in Adelaidc: Convention Debates, Adelaide, 1897, 168-82. See also Sawer, supra, note 3 at 177-78.

31. See generally J. Finnis, "Reforming the Expanded External Affairs Power," Appendix $C$ to the Report of the External Affairs Subcommittec. Procecdings of the Australian Constitutional Comvention. Brisbane, 1985, II, 24. 
Nor should one ignore the fact that nothing succeeds like success. At least from the beginning of the First World War, the Commonwealth was (in politico-constitutional terms) in the ascendant, and the States in decline. From that point on, the collective prospects and dignity of the States - their institutional aura, if one likes - had begun to take on the slightly seedy character which attends entities in decline. This evident decline could only give added weight to the idea that the States were creatures of the past, whose remaining shreds of influence were to be minimised as quickly and expeditiously as possible. Moreover, it is a commonplace of history that at least from the nineteentwenties, western society as a whole became increasingly convinced both of the necessity and ability of governments to manage the economy, and other large scale institutions. This unprecedented role for government suggested the need for that government to be as cohesively organized as possible. In Australia, the Commonwealth was the beneficiary of this logic.

All these factors have combined over the years to produce a climate of thought in Australia in which it has been intellectually unfashionable for many years to be a serious protagonist of the States. In this sense, the High Court's centralism (and its allied constitutional literalism) is as much a predictable product of its intellectual milieu as of any unusual inclination of its own. If politicians, academics, entrepreneurs, generals and trades unionists cry for increased Commonwealth power, it is far from startling that the Judiciary had done its best to give it to them.

This analysis is not comprehensive, but it gives some idea of the reasons for the Court's attachment to centralism, and thus to literalism. Ironically, of course, to the extent that literalism is underpinned by centralism, one is faced with the spectacle of a constitutional methodology whose avowed essence is an inadvertence to political issues, but whose intellectual genesis lies in precisely such considerations.

However, as suggested above, the High Court's attachment to literalism is not entirely political. While a judge like Isaacs may have acted upon political motives, other judges would have been affected by certain aspects of Australia's legal-judicial culture. Even to Isaacs, the appeal of such purely legal considerations was presumably not irrelevant. Lawyers know only too well how difficult it is to separate politics from legal principle, not merely in the actions of others, but within one's own mind.

The first of these factors is that the majority judges in Engineers were on firm ground when they said that it was established law that British statutes were to be interpreted literally. ${ }^{32}$ A proponent of literalism could point to a wealth of supporting authority, which would have weighed heavily on the mind of any 'traditional' lawyers. Indeed, to many of the 'black-letter' positivist lawyers of the 1920s (and later), there can be no doubt that the words of Isaacs in Engineers, in an exclusively legal sense, had and continue to have the ring of pellucid truth. Just as legislators construed a wills statute or

32. See supra, text accompanying note 7; and see e.g. The Sussex Peerage Claim (1884), 11 Cl. Fin. 85. 
a taxation act according to the exact tenor of the words, no more and no less, so they should interpret the Constitution. Thus, when Engineers made its call for literalism, it was playing upon a strong, conservative, and literalistic Australian legal tradition.

One of literalism's other chief attractions has been its surface plausibility as a comprehensive denial that the work of the court is political. The point here is that a literalist judge can say with some force (and, if necessary, injured innocence): 'I am only interpreting the words as they stand - what else would you have me do?' To many judges, this was undoubtedly a camouflage, but to others it has been a genuinely reassuring constitutional mantra. Even today, one can find judges solemnly praising the Engineers decision on the grounds that it prevented the Court from becoming involved in the political disputes of federalism. ${ }^{33}$ Indeed, to a limited extent, this is right: for the literalism of Engineers ironically provides not only a cover for the judicial politician, but a dogmatic ivory tower for the legalistic judge forlornly determined not to engage in politics.

Literalism in addition makes a facile promise of certainty. Instead of having to grapple with such airy and elastic concepts as 'federalism' or 'the nature of the compact', a judge can retreat to the apparent safety of the explicit text, and summon up a battery of semantic and interpretative rules which will 'automatically' dispose of constitutional issues. Of course, an unelaborated text cannot be certain in this dispositive sense. There is always ambiguity and shades of ambiguity. But, being human, those who purport to interpret a constitution 'literally' are all too ready to assume that the construction of the words which they have arrived at is the only one possible. Indeed, in this context, one might argue that not only is literalism 'certain', it is also comparatively easy: one might even be tempted to say that it is lazy. Under such an approach there is neither the need to tease out a scheme from the Constitution, nor the requirement that it be interpreted within a potentially confusing historical context. Engineers literalism has, in short, relieved the High Court of the trying necessity to develop a serious theory of constitutional interpretation. Instead of developing such a theory, the Court has simply asserted the utility of a particular interpretative methodology.

A final factor is that the literalism of Engineers has been subjected to remarkably little intellectual criticism, a most appealing characteristic in an interpretative method. Whereas the United States Supreme Court has had to face the fact that whatever approach it adopts to constitutional interpretation - liberal or conservative, textual or non-textual - it will face vehement opposition from one section or another of the American constitutional intelligentsia, the High Court has not been so constrained. On the contrary, the mainstream position of both Australian political scientists and academic constitutional lawyers has been a highly centralist one, very much in sympathy with the results achieved 
by Engineers. ${ }^{34}$ Consequently, the thrust of the Court's constitutional methodology has been free to operate substantially without the need to cope with sustained hostile criticism. ${ }^{35}$

\section{THE FALL FROM GRACE OF LITERALISM}

What is attempted here is an explanation as to why the hold of literalism has begun to weaken at this juncture in Australia's constitutional history, and of the factors which underlie the diminishing enthusiasm of the High Court for its anointed interpretative method. It may be noted at the outset that a wide variety of considerations have interacted to lessen literalism's attractiveness to the Court, and it should also be appreciated that not all of these factors lead towards both alternative interpretive strategies identified earlier in this article: some would promote an approach based on intentionalism, others would adopt "progressivism."

The starting point here must be to return momentarily to ground already covered: literalism has never been an intellectually satisfying constitutional methodology. Thus, in examining its declining popularity, one has to keep in mind that it has always possessed the vulnerability of an intrinsically flawed doctrine. Nevertheless, this does not explain why Engineers literalism has started to come under sustained challenge now, rather than at some earlier juncture in its career. To a very large extent, Australian constitutional literalism is as much a victim of time as of anything else. The sheer burden of solemnly adhering to interpretative propositions which are far from satisfactory has produced a strain which has become harder to bear with each passing year, and each threadbare articulation. Engineers literalism is afflicted with plain old age.

Quite apart from the affluxion of time, however, there are a number of reasons why Engineer $s$ literalism is presently under threat. One of the most important of these is the general decline of confidence on the part of Australian lawyers in the certainty and determinacy of statutory language, evident across the whole spectrum of the law, but nowhere more pronounced than in the context of the interpretation of written constitutions. ${ }^{36}$ Over forty years of assaults upon the concept of textual certainty have now produced the result that most thinking Australian lawyers would view with amusement the proposition that complex statutory language, especially the broad language of a constitutional document, can be understood in the splendid literal isolation enshrined

34. For example, the writings of Professor Sawer are from a professedly pro-central standpoint: see Sawer, supra, note 3 at 197. Professor Howard's work (especially Australian Federal Constitutional Law, first published in 1968, with further editions in 1972 and 1985) is also generally sympathetic to the High Court's extension of Commonwealth power. Similar comments could be made of the work of Professor Zines, as exemplified in The High Court and the Constitution, supra, note 9.

35. But sce e.g. Dawson, supra, note 6; Finnis, supra, note 31.

36. For an outline of a 'critical' approach to interpretation sec e.g. M. Kelman, A Guide to Critical Legal Studies (Cambridge, Mass: Harvard University Press, 1987) at 213-35; and see M. Tushnet, "Critical Legal Studies and Constitutional Law: An Essay in Deconstruction" (1984) 36 Stanford Law Review" 623. 
in cases like Engineers. By and large,we have embraced (or at least accepted) a notion of textual ambiguity, and readily admit that a vast quantity of both constitutional and statutory language is susceptible of competing meanings which simply cannot be convincingly resolved by resort to the text alone.

These influences could hardly have been expected to by-pass the High Court, which now shows a significantly increased willingness to admit to the possibility that constitutional language might be profoundly ambiguous. ${ }^{37}$ In this connection, there are a number of factors which have facilitated the infiltration of such notions into the Court's jurisprudence. One is the increasing interest shown by a number of members of the Court in North American constitutional theory and jurisprudence. ${ }^{38}$ The point here is that if Australian lawyers are beginning to feel that a faith in the utter determinacy of constitutional language is a little dated, to American and Canadian scholars - and courts - the literalism of Engineers must seem positively antediluvian.

A further relevant factor is the Court's increasing interest in legal theory, including constitutional theory, which can only lead to an acute appreciation of the fact that constitutional literalism makes no real attempt to present a coherent theoretical vision of the Australian Constitution and its interpretation. ${ }^{39}$ The concern of a number of the Judges to delve more deeply into the specific field of constitutional theory, and to at least begin the task of articulating a vision, as opposed to conducting a dissection of the Australian Constitution, is now plainly evident. ${ }^{40}$ To the extent that the Court's emergent vision of a self-sustaining Australian law and legal system ${ }^{41}$ requires as an essential component a serious constitutional theory, together with a derivative methodology of constitutional interpretation, the literalism of Engineers as such has virtually nothing to offer.

It is worth noting here the potential symbolic importance of the 1986 Australia Acts. ${ }^{42}$ As much as anything else, these Acts exemplify the attainment by Australia of full

See e.g. Bourke v. State Bank of New' South Wales (1990), 93 A.L.R. 460 at 463-65; Phillip Morris Lid. v. Commissioner of Business Franchises (1989), 87 A.L.R. 193 at 201, Mason C.J. and Deane J.: 239-41, Toohey and Gaudron J.

38. For examples of such influence see c.g. Mason, "The Role of a Constitutional Court in a Federation - A Comparison of the Australian and the United States Experience" (1986) 16 Federal Law Review 1 originally delivered at the University of Virginia Law School: Mason, "Future Directions in Australian Law" (1985) 13 Monash University Law' Review 149 at 160-61: McHugh. "The Lawmaking Function and the Judicial Process - Pan I" (1988) 62 Australian Law Journal 15 at 16-17 and 26-31.

39. See for example the references cited ibid:; and see the judgment of Deane J. in Metwally v. University of Wollongong (1984), 158 C.L.R. 447 at 476-78; and of Brennan J. Kioa v. West (1985), 159 C.L.R. 550.

40. Ibid.

41. Sec especially Mason, "Future Directions in Australian Law" supra, note 38 at 149-55.

42. These acts are conventionally regarded as having terminated United Kingdom legislative authority over Australia. See generally G. Lindell. "Why is Australia's Constitution Binding? The Reasons in 1900 and Now, and the Effect of Independence" (1986) Federal Law Review 29. 
constitutional and legal independence. However convenient it may have been for Australians to muddle along on the prosaic instrumentalism of Engineers while their nation was umbilically linked to the placenta of Britain's own constitutional self-vision, the sundering impact of the Australia Acts is a potent force for the articulation of a new, comprehensive conception of what the Australian Constitution is, and what a Court is doing when it interprets it.

Quite apart from the growing acceptance that language is an inexact legal tool, there has been a pronounced trend in recent years, both within and without Australia, towards the purposive, non-literal construction of statutory provisions. In Australia, this was very largely fuelled by wide-spread community feeling against the High Court's application of literalist techniques very similar to those endorsed in the Engineers case for the purpose of narrowly confining the scope of remedial taxation legislation. ${ }^{43}$ The primary outcome of this feeling has been the enactment of statutes in both the State and Federal spheres directing courts to prefer a purposive over a technical construction, ${ }^{44}$ and liberalising the rules concerning the use of extrinsic, non-textual materials. ${ }^{45}$ Indeed, quite apart from these legislative initiatives, there appears to have been something of a change of heart on the part of the courts themselves. ${ }^{46}$ The net result is that in the field of statutory interpretation, we have seen a marked general swing towards intention-based, nonliteralist, purposive construction. It can come as no particular surprise that such a movement cannot be quarantined from the closely allied field of constitutional interpretation. It is true that the relevant reforming Commonwealth legislation specifically does not apply to the interpretation of the Constitution. But Judges will be influenced by movements within general jurisprudence and interpretive procedure. ${ }^{47}$ It may be noted that influences such as these clearly enough propel the Court away from literalism in the specific direction of what has been referred to above as 'intentionalism'.

There are jurisprudential trends which are influencing judges towards "purposive" interpretations. One increasingly important aspect of the functioning of the Court has been its growing acceptance and confession that it is in the business of making the Constitution as it interprets it. ${ }^{48}$ Under the influence of realist and post-realist thought, many members of the Court now accept that, while they are not unconstrained by the text, they have considerable latitude in channelling the meaning of that text. As Goldsworthy

43. See e.g. D. Pearce and R. Geddes, Statutory Interpretation in Australia, 3rd ed., (Sydney: Butterworths, 1988) at 29-30; Macrossan, J., "Judicial Interpretation" (1984) 58 Australian Law" Journal 547.

44. In the Commonwealth sphere section 15AA of the Acts Interpretation Act; in Victoria, for example, section 35 of the Interpretation of Legislation Act 1984.

45. See e.g. Acts Interpretation Act (Cth.), section 15AB; Interpretation of Legislation Act 1984 (Vic.), section 35.

46. See e.g. Cooper Brookes (Wollongong) Pty. Ltd. v. Federal Commissioner of Taxation (1981), 35 A.L.R. 151; Wacando v. Commonwealth (1981), 37 A.L.R. 317.

47. See e.g. Cole v. Whirfield (1988), 165 C.L.R. 360.

48. See e.g, Mason, "The Role of a Constitutional Court in a Federation" supra, note 38 at 22-23; "Future Directions in Australian Law" supra, note 41 at 160-62; Koowarta, supra, note 15 at 225. 
says, we are all realists now. ${ }^{49}$ Thus, an increasing number of High Court judges would regard the proposition that they are mere media for the transmission of a determinative constitutional text as little short of bizarre. To such judges, there is a powerful temptation to abandon the encumbering trappings of literalism, and to engage in what is probably the more risky but infinitely more intellectually defensible (and honest) exercise of interpreting the Constitution in accordance with the perceived needs of contemporary Australian society, or whatever other formulation of the same concept they may choose to espouse. Adoption of this approach would amount to the 'progressivism' described above. Of course, it is not suggested that such judges would entirely abandon the text: rather, they would be inclined to embrace a concept of pervasive constitutional ambiguity, and utilize their conception of an ideal Australian society to fill in the resulting gaps.

A matter operating in the same direction is the widespread belief in Australia that the constitutional amendment process has 'failed', a belief apparently held by some members of the Court. ${ }^{50}$ The idea here is that the electorate has proved perversely stubborn in resisting constitutional reform, and has tended to vote 'No' at referenda more out of an unreasoning innate conservativism than upon any considered view as to the merits of particular proposals. ${ }^{51}$ The point in this context is that any judge firmly of the view that the Constitution is in need of significant reform, and that such reform will never be achieved under section 128 , will at least be tempted to try to secure that reform through a process of judicial interpretation. Obviously, literalism is not an interpretative technique that is openly sympathetic to such a process, however much it may be pressed into service as an intellectually unsatisfying cover for a (centralising) 'reformist' agenda. The methodology of progressivism, by way of contrast, would provide a principled base from which a right-minded judge could pursue the reform of the Constitution openly and more or less comprehensively.

A more subtle influence is the growing awareness of Australian lawyers that their discipline is not an isolated and self-contained domain of knowledge. The relevance of such other disciplines as history, economics, political science and sociology has been accepted in the law schools, and is in the process of forcing itself upon the courts. The High Court, for example, is now painfully aware that it cannot simply rely on 'pure law' and eschew all knowledge of economics when it comes to apply sections 90 and $92 .{ }^{52}$ The increasing importance of history in the process of constitutional interpretation has also become apparent in a number of contexts. ${ }^{53}$ Influences such as these open the Court's task of constitutional construction, and militate against literalism.

Goldsworthy, supra, note 2 at 51.

See Mason, supra, note 38 at 22.

See e.g, Sawer, supra, note 3 at 207-08; Coper, supra, note 9 at 374-80.

Section 92 guarantees freedom of interstate trade, section 90 gives the Commonwealth a monopoly over "customs and excise." See for example the decision of the Court in Bath v. Alston Holdings Pry. Lrd. (1988), 78 A.L.R. 669; and the criticisms of that decision in the case note by C. Howard, in (1988) 16 Melbourne University Law Review 852; and see Phillip Morris Lid., supra. note 37. E.g. section 92 (see Cole, supra, note 47, and the corporations power (see New South Wales v. Commonwealth (1990), 64 A.L.J.R. 157). 
To an extent, it may also be argued that literalism is in decline because it has substantially achieved the purpose for which it was designed. Seventy years after Engineers, the goal of centralising power in the Australian Federation has largely been attained. It is true that the States retain a significant residue of legislative competence, but there is little the Commonwealth cannot achieve. ${ }^{54}$ To this extent, the necessity that largely prompted the Court's original adherence to literalism - that of achieving a transfer of power from the States to the Commonwealth - has substantially disappeared. Arguably, therefore, the Court is free to discard a literalism that has outlived much of its usefulness.

Paradoxically, a further potential incentive for the Court to abandon literalism is that it may in fact have been a little too successful in achieving a centralization of power in Australia. While the present High Court is hardly known for its attachment to federalist values, it has had occasion to look askance at the Commonwealth juggernaut it helped create, especially in terms of the enormous power wielded by a Commonwealth executive firmly in control of the House of Representatives. ${ }^{55}$ It may be that the Court could be tempted to relax its literalism in the cause of securing for the States a little more breathing room, if only to provide some sort of balance to the pervasive political power of the Commonwealth. ${ }^{56}$ This balance is, after all, one of the chief theoretical advantages claimed for federalism. ${ }^{57}$

Finally, to the extent that the federal balance of power is largely a dead (or comatose) issue in Australian constitutional law, it is natural enough for the Court to look for new areas of constitutional endeavour. Indeed, without federal division of power cases, and with nothing else substituted, the High Court of Australia becomes a fairly pedestrian court of appeal. The most obvious possibility would be for the Court to devote itself to the development of constitutional guarantees of democratic and individual rights, a currently fashionable field which it has so far neglected, but in which a number of its members show a lively interest. ${ }^{58}$ The problem with literalism in this context is that, however apt it may have been as a tool of centralism, it is quite useless as a means of propounding rights which simply do not appear on the face of the text. For this task, a far more free-wheeling constitutional approach, permitting in particular massive resort to implications, would be necessary.

See B. Galligan, "Federal Theory and Australian Federalism: A Political Science Perspective" in B. Galligan, ed., Australian Federalism (1989) 45.

See G. Craven, "A Few Fragments of State Constitutional Law" (1990) 20 University of Western Australia Law Review 353 at 368 . Such influences might be discerned in decisions like Brown v. West (1990), 64 A.L.J.R. 204, and even New South Wales, supra, note 53. See e.g. New' South Wales, ibid; Street, supra, note 25.

See Dawson, "The Constitution" supra, note 6 at 364-5; Galligan, "Federal Theory" supra, note 2 at 54-60.

See Mason, "Directions in Australian Law" supra, note 38 at 162-63; University of Wollongong, supra, note 39 at 476-78, Deane J: Union Steamship Co. Pty. Lid. v. King (1988), 82 A.L.R. 43 at 48. 


\section{THE CHALLENGES TO LITERALISM}

It already has been suggested in this article that there are presently two incipient challenges to literalism as the orthodoxy of constitutional interpretation in Australia. These were labelled 'progressivism' and 'intentionalism'. What is attempted now is an account of the emergence of these two challenges; an explanation of their essential hostility to literalism; an analysis of the implications which the triumph of either would hold for the future direction of Australian constitutional interpretation; and a consideration of whether it would be possible to synthesize elements of all these competing interpretative approaches - progressivism, intentionalism and literalism - into a single, principled methodology.

\section{A. PROGRESSIVISM}

The term 'progressivism' has been chosen to describe an approach to constitutional interpretation which maintains that provisions should be so interpreted as to give them the meaning most consonant with the recognition and satisfaction of the needs of contemporary Australian society. A crucial component of a progressivist approach to constitutional interpretation in Australia will ordinarily be a belief that much of the language of the Constitution is profoundly and generally ambiguous, and therefore open to moulding in accordance with this or that progressive agenda without doing actual violence to the text.

A progressivist will thus see one of the most basic responsibilities of the High Court as keeping the Constitution 'up to date'. Of course, one dynamic of any system of constitutional interpretation must be a desire that the constitution does not become hopelessly out of touch with society. The important issue is more the extent to which such a concern becomes an overtly controlling principle of constitutional interpretation at which point one may be said to have reached progressivism - than whether it has any influence at all.

Because there is always a progressivist element in constitutional interpretation, it might be argued that there is nothing particularly 'new' about the progressivism considered in this article. For example, one could point to such statements of judicial realpolitik as the much-quoted dictum of Windeyer J. in Victoria v. Commonwealth, ${ }^{59}$ that the decision in Engineers itself involved reading the Constitution in a 'new light', a light shed by political and social developments in Australia following Federation. But such overt articulations of what could be regarded as something approaching a progressivist 
position ${ }^{60}$ have hitherto been extremely rare. ${ }^{61}$ This is logical enough when one remembers the intensely textual, 'non-political' nature of Australian literalism. ${ }^{62}$

In the United States a version of 'progressivism' has long been a recognized approach to constitutional interpretation, and has been advanced in a variety of forms, some (by Australian standards) extreme. Certain American scholars have asserted not merely that the text of the United States Constitution should be interpreted progressively, but that the text itself is essentially devoid of moral or legal authority, and the Supreme Court is thus entitled to mould the constitutional pronouncements more or less freely in accordance with its own 'progressive' values. ${ }^{63}$ Other American progressivists are gentler with the text, and more closely approach the resolution of ambiguity model outlined above, although even these are inclined to move far enough away from the actual words of the Constitution as to nonplus the Australian constitutionalist. ${ }^{64}$

It is quite clear that any Australian version of progressivism would necessarily be weaker than its American counterpart. There are at least two reasons for this. First, the Australian Constitution does not contain a Bill of Rights composed of infinitely vague and elastic provisions which guarantee basic social and political rights. Thus, both the opportunity and much of the temptation to engage in a wholesale re-working of the Constitution's dispositions is diminished. Second, the extreme version of American progressivism, which actually denies the binding authority of the Constitution, is simply too antithetical to too many of Australia's constitutional assumptions and attitudes to take root. Whatever other arguments may excite Australian constitutional law and theory, it is a given that the Constitution is authoritative: the controversy is really over how to ascertain what the Constitution means. The net effect of all this is that any Australian school of constitutional progressivism will start from the position that the Constitution is supreme, but will go on to stress the open-ended nature of its terms, and the corresponding necessity that they be understood in light of constantly changing circumstances. Such views will most likely be gathered together under the rubric of the

It is in any event far from clear that Windeyer $J$. was intending to endorse anything more than the particular interpretative techniques adopted in Amalgamated Society of Engineers.

6. Perhaps the clearest application of a progressivist approach in an actual decision of the Court is by Mason J. in Koowarta, supra, note 14 at 224-25. A very clear articulation of progressivism appears in Mason, "The Role of a Constitutional Court" supra, note 38 at 22-23.

62. It is also the case that there is an element of progressivism in one of the High Court's favourite interpretative notions: that the connotation of a term remains constant, but its denotation changes over time: see c.g. Zines, supra, note 9 at 16-17. But this is still far removed from the conscious and explicit revision of the Constitution.

63. One has in mind here the work of such theorists as Laurence Tribe (see e.g, Constitutional Choices (1985)), and Mark Tushnet (see e.g. Red, White and Blue: A Critical Assessment of Constitutional Law (1988)); "Critical Legal Studies and Constitutional Law: An Essay in Deconstruction" (1984) 36 Stanford Law Review' 623).

at. See e.g. the work of A. Bickel, The Least Dangerous Branch (Indianapolis: Bobbs-Merrill, 1962) and J. Ely, Democracy and Distrust: A Theory of Judicial Review (Cambridge: Harvard University Press, 1980). See also generally R. Bork, The Tempting of America: The Political Seduction of the Law' (1990). 
proposition that the Constitution is a deliberately vague document, meant to be moulded and adapted over the course of time by policy-directed judicial decision.

Progressivism is presently less a fully articulated school of thought on the High Court than an emergent tendency. Nevertheless, keeping in mind some of the factors identified above as being particularly conducive to its evolution, ${ }^{65}$ it is possible to discern its first stirrings. Probably the closest approach to the articulation of a consciously progressivist interpretative methodology is comprised in the 1986 article of the present Chief-Justice, Sir Anthony Mason. ${ }^{66}$ Sir Anthony's central thesis, developed specifically in the context of the federal division of powers, ${ }^{67}$ is that the Constitution is not a monolithic block of determinate meanings. On the contrary, it is a comparatively loosely structured document, to be 'dynamically' adapted by the Court to changing circumstances. While the text is supreme, the understanding of that text is volatile, and changeable in the hands of a Court responsive to current problems and events. The duty of the Court to keep the Constitution 'up to date' is reinforced by the 'cumbersome' nature of the amendment process. ${ }^{68}$ The critical passage is as follows:

The problem is that the words of the Constitution have to be applied to conditions and circumstances that could not have been foreseen by its authors. It follows that exploration of the meaning of the language of the Constitution at the time of its adoption and the intentions of the authors have a limited value in resolving current issues. Accordingly, there is a natural tendency to read the Constitution in the light of conditions, circumstances and values of our own time, instcad of freezing its provisions within the restricted horizons of a bygone era. Viewed in this way, the Constitution is not so much a detailed blueprint as a set of principles designed as a broad framew'ork for national government. ${ }^{64}$

Other High Court judges appear to be thinking along the same lines. Thus, Justice McHugh has argued strongly in general term $\mathrm{s}^{70}$ for an increased judicial activism in light of the need to adapt Australian law to an unprecedented degree of social change." Responding to the usual charge levelled against judicial activism, namely, that it is undemocratic, McHugh J. trenchantly responds:

In certain situations, invoking democratic rhetoric to legitimise the refusal to deliver justice is itself undemocratic, particularly when legislative reform is unlikely. When a legislature fails to recognize and address a problem of law reform, the use of democratic rhetoric to deprive the courts of the opportunity to contribute to the development of the law and the doing of justice is highly questionable. The courts, as much as the legislatures, are in continuous contact with the concrete needs of the community. ${ }^{72}$

65. See supra, text accompanying notes 36-58.

66. Mason, "The Role of a Constitutional Court in a Federation" supra, note 38. See also Mason. "Future Directions in Australian Law" supra, note 38 at 155-163.

67. Mason, "The Role of a Constitutional Court" supra, note 38 at 22-23.

68. Ibid. at 22.

69. Ibid. at 23 [emphasis added].

70. McHugh, "The Law-making Function of the Judicial Process - Part II" supra, note 38 at 116.

71. Ibid. at 116.

7. $\quad$ bid. at $122-23$. 
Instances of overt progressivism are rather rarer in the cases than in the extra-curial writings. This is partly because progressivism can be difficult to discern amidst the application of other, more staid judicial techniques: for example, the identification of an 'evident' purpose behind ${ }^{73}$ a particular constitutional provision, which just happens to produce the social or other results desired by the judge in question. Nevertheless, the influence exerted by the perceived desirability of particular policy results is increasingly traceable in the reasoning of judges over the past ten years, and emerges most clearly in some of the cases relating to Commonwealth powers with respect to external affairs, ${ }^{74}$ corporations, ${ }^{75}$ and the imposition of excise duties. ${ }^{76}$

Perhaps the clearest instance of a judge adopting a progressivist approach is (not surprisingly) that of Sir Anthony Mason in Koowarta v. Bielke-Petersen. ${ }^{77}$ In that case, His Honour obviously regarded the suggested policy advantages of a broad Commonwealth power of treaty-implementation as being highly relevant to the interpretation of the external affairs power contained in section 51(29). Thus, he observed of the view that Commonwealth legislative power was not so extensive, and that effective treaty-implementation would in many instances depend on legislative action by the States:

The ramifications of such a fragmentation of the decision-making process as it affects the assumption and implementation by Australia of its international obligations are altogether too disturbing to contemplate. Such a division of responsibility between the Commonwealth and the States would be a certain recipe for indecision and confusion, seriously weakening Australia's stance and standing in intemational affairs. $^{78}$

It is important to appreciate the essential antipathy between literalism and this sort of progressivism. That antipathy lies in the fact that progressivism typically rejects any concept of the 'natural' or 'literal' meaning of the text in favour of a general perception of ambiguity - or at least of a range of possible meanings - within which policy perceptions of current social needs are deployed to arrive at a desirable interpretation.

It would be possible to argue, especially in the crucial context of the federal division of powers, that the adoption of a progressivist approach would simply involve an overt articulation of precisely the same policy considerations that have always lain behind Engineers-style literalism, namely, those relating to the general desirability of enhanced central power. There is some truth in this point, but it should not be overplayed. In the

One might suspect the operation of such considerations, for example, in relation to the interpretation of section 90: see e.g. Hematite Petroleum Pty. Lid. v. Victoria (1983), 151 C.L.R. 599, 630-32, Mason J.; 660-62, Deane J.

74. E.g. Koowarta, supra, note 14; Commonwealth, supra, note 14.

75. E.g. Actors and Announcers' Equity Association v. Fontana Films Pty. Ltd. (1982), 150 C.L.R. 169; State Superannuation Board v. Trade Practices Commission (1982), 150 C.L.R. 282; Commonwealth, supra, note 14.

76. E.g. Hematite Petroleum Pty., supra, note 73.

77. (1982), 153 C.L.R. 168.

78. Ibid. at 225 . 
first place, the profound difference in terms of interpretative theory between a literalist and a progressivist approach cannot lightly be dismissed. Secondly, the overt articulation of policy arguments would produce not only a totally different constitutional 'style' on the High Court, but would also impose new burdens upon it (the relevant policy arguments would need to be clearly thought out and presented in a convincing manner), as well as exposing the Court to all the usual and well-rehearsed dangers which attend a judicial body adrift on the sea of policy. ${ }^{79}$ Finally, as has been suggested ${ }^{80}$ literalism is largely unable to service a policy agenda much beyond the centralization of power, whereas progressivism has at least the potential to carry the Court into new and exciting areas such as the implication of fundamental human rights.

This is not to say that there can be absolutely no point of intersection between literalism and progressivism, or at least between textualism and progressivism. As has been noted, more extreme forms of progressivism which virtually negate the text could find no place in the Australian constitutional tradition: the Constitution, once understood, must be accorded primacy. Thus, even the most committed progressivist Australian judge, if faced with an entirely unambiguous piece of constitutional language, would acknowledge him or herself bound, and at this point progressivism and textualism may be regarded as being in uneasy equilibrium. But the concept of ambiguity is a seductive one. Once it is accepted that the terms of the Constitution are ambiguous, and that when found to be ambiguous are to be interpreted in such a way as to fulfil the current social needs of the nation, the temptation to discern the necessary degree of ambiguity will frequently be irresistible, while the opportunities to do so will be immense. The idea that literalism and progressivism are ultimately consistent because the latter will only be brought into play in the exceptional case of ambiguity is essentially a fool's hope.

\section{B. INTENTIONALISM}

The second current challenge to literalism has been designated here as 'intentionalism'. Other names could have been chosen, notably 'originalism', but this has been rejected on the grounds that it carries with it connotations derived from American constitutional jurisprudence which are not necessary components in any Australian debate. ${ }^{81}$

The central element of an intentionalist approach is reasonably obvious: it posits that the overriding duty of the Court is to give effect to the intentions of those who formulated the Constitution. The search for this sacred intention is absolute, and thus not to be gainsaid by reference to other considerations, including technical rules of legal construction. Were one to identify the underpinning rationale of intentionalism, it would

See e.g Sir Ninian Stephen, "Judicial Independence: A Fragile Bastion" (1982) 13 Melbourne University Law Review 334.

so. $\quad$ See supra, text accompanying notes 54-58.

81. For a general account of intentionalism in Australian constitutional law see G. Craven, "Original Intent and the Australian Constitution - Coming Soon to a Court Near You?" (1990) I Public Law Review 166. See also Dawson, supra, note 6. 
undoubtedly be found to lie in a vision of democratic principle. The Australian intentionalist would argue that the Constitution, having been generated through a process which accorded with principles of representative democracy, ${ }^{82}$ and popularly ratified at referenda ${ }^{83}$ is to be faithfully applied by the courts in fulfilment of the intentions of the delegates of the colonial populations who framed it. Even more than progressivism, elements of intentionalism have always been present in Australian constitutional law. ${ }^{84}$ At a very basic level, our constitutional jurisprudence is replete with formalistic references to the 'intention' and 'purpose' behind particular provisions. More importantly, even the dominant literalism of Engineers is, at least in theory, based upon the assertion that it provides the best means of divining 'the intention'. ${ }^{85}$

However, it should not therefore be thought that there is little difference between a literalist and an intentionalist approach. To an Engineers-style literalist, the bare text is both the beginning and the end of the search for intention. To the pure intentionalist, however, who regards the text as a mere servant of intention, it occupies a far less lofty position, and further sources of intention (such as Convention Debates ${ }^{86}$ or other historical materials) also are relevant. Moreover, even an intentionalist who would concede the conclusiveness of an unambiguous text will be eager to inject other sources of intention into the constitutional equation in the event of uncertainty. In this sense, the moderate intentionalist and the moderate progressivist will have common willingness to embrace the concept of an essentially ambiguous Constitution in order to allow greater scope for the free operation of their chosen interpretative methodology.

'Intentionalism' or 'originalism' has had a stormy history in the United States, where it has acquired strong right-wing political associations. It has often been resorted to in that country by those who are eager to wind back what they see as socially ruinous 'liberal' interpretations placed by the Supreme Court upon the open-textured provisions of the Bill of Rights. ${ }^{87}$ It should be noted that an Australian intentionalist would in no sense be committed, even incidentally, to a corresponding political or social agenda. To the extent that the High Court's literalism has subverted the original intention of the Australian Founders, the main result simply has been the greater centralisation of power. Thus, while a return to that intent might well effect some change in the context of

82. The Constitutional Conventions of the 1890 s were popularly elected: see J. Quick, and R. Garran, The Annotated Constitution of the Australian Commonwealth (1901) 163-5; Craven, ibid. at 177.

lbid.

See supra, text accompanying note 7.

Ibid.

The Convention Debates are the 6,000 pages of printed verbatim debates of the delegates who framed the Australian Constitution between 1891 and 1897. They were reprinted (with a detailed guide and indices) in 1986: see Crawford, "The Legislative Power of the Commonwealth" in G. Craven, ed. The Convention Debates 1891-1898: Commentaries, Indices and Guide (Carlton: Melbourne University Press, 1986).

87. See e.g. R. Berger, Federalism: The Founders' Design (Norman, Oklahoma: Universitty of Oklahoma Press, 1987); Bork, supra, note 64. 
federalism, it could not be represented as serving an inherently conservative social or political agenda.

As with progressivism, a meaningful intentionalism is at present merely an emergent tendency on the High Court, although its course is reasonably easy to mark. The posture of the Court towards intentionalism is probably best reflected in the view it takes of the use of the written Debates of the Founding Fathers (the Convention Debates). A strongly literalist approach will prompt exclusion of the Debates, on the basis that it is the words of the Constitution themselves which are dispositive. Under an intentionalist methodology, the Debates will be highly relevant as contributing to an understanding of the crucially important historic intent, particularly in cases of textual ambiguity.

Traditionally, the High Court has eschewed all use of the Debates. ${ }^{88}$ But this ban, which actually pre-dated Engineers, ${ }^{89}$ has quite recently collapsed, coincidentally with the first republication of the Debates themselves. Thus, in Cole v. Whitfield ${ }^{00}$ the Court cautiously reassessed its position, holding that while the Debates could not be used to substitute the subjective intention of the Founders as to the meaning of particular words for the meaning conveyed by the language itself, they could be consulted "for the purpose of identifying the contemporary meaning of the language used, the subject to which that language was directed and the nature and objects of the movement towards federation from which the compact of the Constitution finally emerged."91 Probably the best way of understanding this rather opaque dictum is to see it as permitting recourse to the Convention Debates (and thereby to the expressions of subjective intention which they contain) in the event of ambiguity in the actual text.

It is beyond question that the use of the Debates in this way in Cole itself had a significant effect upon the chaotic jurisprudence of section 92, but the full impact of the Court's new attitude to the deliberations of the Great Conventions was not felt until last year in the landmark decision of New South Wales v. Commonwealth (the Corporations case). ${ }^{92}$ In that case, the profoundly ambiguous words of section $51(20)^{93}$ were held not to allow the Commonwealth to legislate with respect to the formation of corporations. The crucial factor in the majority judgment was undoubtedly the views of the Founders as revealed by a consultation of the Convention Debates. ${ }^{94}$ The Court did not really go

Municipal Council of Sydney v. Commonwealth (1904), 1 C.L.R. 208; Tasmania v. Commonwealth (1904), 1 C.L.R. 329.

89. Although it is clear that the Court made indirect use of the debates, if only by considering the historical accounts in Quick and Garran, supra, note 82: see e.g. Re Pearson; Ex parte Sipka (1983), 57 A.L.J.R. 225.

(1988), 165 C.L.R. 360.

Ibid. at 385.

(1990), 64 A.L.J.R. 157.

The issue was whether a Commonwealth power to make laws with respect to "... corporations ... formed within the limits of the Commonwealth" allowed the Commonwealth to regulate the incorporation of companies.

94

Ibid. at 164-66; see also Craven, supra, note 81 at 183-185. 
beyond the proposition contained in Cole concerning the use of the Debates, but this surprising and important victory for the States dramatically emphasized the emerging importance of intentionalism. On the basis of decisions like Cole and the Corporations case, it would seem that a moderate version of intentionalism is indeed emerging on the Court, according to which both Debates and 'subjective' intention will be regarded as irrelevant where the words of the Constitution evince a clear and certain meaning, but will be considered for the purpose of resolving ambiguity.

Lest such an approach be thought to differ but little from the High Court's traditional literalism, its full implications should be considered. Once again, ambiguity - and especially some idea of general constitutional ambiguity - is a difficult concept to contain. ${ }^{95}$ The natural tendency of the intentionalist will be to err on the side of discerning ambiguity in order to bring the full panoply of intentional evidence into play. Moreover, particularly in the context of such broad provisions as the tersely expressed placita of section 51, conferring legislative power on the Commonwealth, a finding of textual ambiguity will not be difficult to make out. At this point, techniques very different from those hitherto used by the Court in the disposition of constitutional matters - such as the detailed sifting of the historical record - will need to be brought into play. Thus, even this moderate form of intentionalism poses an enormous challenge to the constitutional methodology espoused in Engineers.

One of the most important points to be made in relation to both emergent challenges to literalism is that, unlike the High Court's traditional literalism, each does offer a basic vision of the role of the Court in its task of constitutional interpretation. Under progressivism, the fundamental duty of the Court is to keep the Constitution, so far as possible, in tune with the changing needs of society. For the intentionalist, the Court is charged with the inviolable task of giving effect to the intentions of the Framers. Interestingly, all three approaches have one thing in common, namely, each is to some extent intention-based: intentionalism directly; literalism intrinsically, in the sense that its conceptual validity depends upon its utility as a means of divining intention; and even progressivism, at least to the vestigial extent that it seems to posit the existence of some basic historical intent that the Court should constantly revise the Constitution. ${ }^{96}$

See supra, text accompanying notes 63-65.

As evidenced by concerns to demonstrate a "progressive" intention on the part of the Founders themselves: see e.g. Crawford, "The Legislative Power of the Commonwealth" in G. Craven, ed., The Convention Debates. supra, note 86; J. Thomson, "Principles and Theories of Constitutional Interpretation and Adjudication" (1982) 13 Melhourne University Law Review 597 at 606. This suggestion is highly implausible as a matter of historic record: see Craven, supra, note 55 at 63-64. In the context of American progressivism see e.g. P. Brest, "The Misconceived Quest for the Original Understanding" (1980) 60 Boston University Law Review 204 at 215-16. 


\section{IMPLICATIONS OF PROGRESSIVISM AND INTENTIONALISM}

Two issues fall for consideration here. The first concerns the general implications for Australian constitutionalism by the adoption of either progressivism or intentionalism as a new constitutional orthodoxy. The second relates to the exact theoretical and practical questions which would have to be faced by the Court in the event that it did choose to follow one or other of these conflicting paths of constitutional interpretation.

As regards the implications which would flow from the High Court's substantial adoption of progressivism, some have already been noted. Thus, it has been seen that the centrality of the constitutional text - at least as comprising a set of objectively and readily ascertainable dispositions of constitutional questions - would be greatly diminished. That text would come to be seen as considerably less determinative, far more ambiguous (or 'open-textured'), and increasingly to be interpreted by reference to competing policy options. ${ }^{97}$

In this connection, Sir Anthony Mason is undoubtedly correct in saying that exposure of policy choices will make for far more open debate of constitutional decisions than that which presently occurs in Australia. ${ }^{98}$ It is, however, much more doubtful whether he and his fellow judges will greatly enjoy the debate once it has begun, or indeed whether they will make much of a fist at winning it. Either way, it is clear both that the overt entry of the Court into the realm of constitutional policy would make for a dramatically freer style of constitutional interpretation, and that the ability of the Court to float above the tempests of political controversy would be correspondingly reduced.

As to the effect of a move towards progressivism upon the Court's attitude to the federal balance of power, it is probably fair to say that such a move would in practical terms bode ill for the States. This is because progressivist judges and thinkers like Mason C.J. have tended to see progressivism as a means of furthering their particular policy judgement that the increased centralization of power in Australia is a worthwhile end in itself. As Sir Anthony has remarked:

...the complexity of modem life, the integration of commerce, technological advance, the rise of the welfare state, even the intrusive and expanding reach of international affairs into domestic affairs, require increasing action on the part of the national government...99

Of course, some might argue that progressivism would in fact involve but a small departure from the past, at least so far as the federal balance is concerned. It would be maintained that the Court would merely pursue a centralizing agenda overtly by way of progressivism rather than covertly by way of literalism. But the overt articulation of policy factors in this context is important if only because judicial motivations are thereby

Mason, "The Role of a Constitutional Court" supra, note 38 at 23. 
exposed to public scrutiny and attack. Moreover, it is very likely that a largely unrestrained recourse to policy factors would have far greater potential to alter the federal balance of power than an often laboured and artificial manipulation of constitutional language.

It is true, however, that the most obvious capacity of progressivism for constitutional development does not lie in the field of Australian federalism. The most dramatic impact of progressivism would be felt in areas of constitutional law which the High Court currently might well wish to develop, but which are not easily susceptible to extension by means of the device of literalism. The prime example is constitutional guarantees of fundamental rights. Were the Court to embark upon a novel career of teasing such rights out of the admittedly unpromising body of the Australian Constitution, literalism as an extractive tool would be next to useless. Progressivism, on the other hand, allied with some fairly broad concept of constitutional implication, would be a far more congenial ally. ${ }^{100}$

Of course, any adherence by the Court to some version of progressivism would acutely raise a whole series of obvious, but quite profound questions concerning its functioning as an agency of constitutional review. The most obvious is the fundamental issue of legitimacy. Critical here would be the relationship between a progressivist Court and the amendment process contained in section 128. The Court could not avoid the argument that the adaptation of the Constitution to the changing needs thrown up by time is to be achieved not by judicial fiat, but via the referendum formula set out in the Constitution. ${ }^{101}$ In such a view (the appeal of which has been acknowledged even by Chief Justice Mason) ${ }^{102}$ progressivism would constitute a usurpation of the basic prerogative of the Australian people to change their own constitutional arrangements.

Controversy over progressivism may rage over ground already burnt-over by earlier conflagrations concerning the role of judges in 'making law', but with the flames fanned to a greater intensity by the fact that the debate would take place in the highly sensitive context of basic constitutional dispositions. Thus, such arguments as those relating to the suitability of judges as fermenters of social change ${ }^{103}$ would be mounted with particular force, and would need to be vigorously countered by proponents of progressivism. In this

There are limited signs that such process has already begun: see Union Steamship Company of Australia Pty. Ltd., supra, note 58; Mason, "Future Directions in Australian Law" supra, note 38 at 163; and "The Role of a Constitutional Court" supra, note 38 at 11-13.

101. Under section 128, the Constitution may be amended by a referendum passed by both a majority of the electors of the Commonwealth as a whole, and by a majority of electors in a majority (i.e. four) of the States.

102. Mason, "The Role of a Constitutional Court" supra, note 38 at 22-23.

103. See e.g. J. Bakan, "Strange Expectations: A Review of Two Theories of Judicial Review" (1990) 35 McGill Law Review 439; "Constitutional Interpretation and Social Change: You Can't Always Get What You Want (Nor What You Need)" (1991) 70 Can. Bar Rev. 307. 
context, it is interesting to recall that McHugh J. has already asserted that the 'courts, as much as the legislatures, are in continuous contact with the needs of the community'. ${ }^{104}$

Certainly, it is undeniable that a High Court seriously committed to progressivism would rapidly descend from the apolitical summits upon which it supposedly dwells, and into the hurly-burly of daily political controversy. However, before the Court could effectively engage in (and defend its decisions as part of) such a policy debate, it would need to considerably refine its argumentative techniques. By this is meant two things. In the first place, if the Court is to make increasingly policy-oriented decisions, it is going to have to develop evidentiary and procedural techniques which facilitate the elucidation of the requisite policy material. To this task, its traditional evidentiary approaches are largely unequal. ${ }^{105}$ Secondly, it will have to do a better job of explaining its preferred policy outcomes than would be suggested by past statements of its current members. For example, the utterances of Mason C.J. cited above, ${ }^{106}$ seem to imply that the more significant the problem, the more self-evident the case that it be dealt with on a national basis, does not sufficiently support the articulation of policy choices in the specific context of the federal division of power. ${ }^{107}$

The implications of a future adherence by the High Court to a doctrine of intentionalism would also be momentous. The general style of Australian constitutional interpretation would be radically changed: the present overwhelming importance attached to the literal meaning of constitutional terms would be greatly diminished, while the ultra-literalism of Engineers would entirely vanish. What could loosely be termed 'historical' research would clearly come to occupy a far more central place than formerly in the High Court's interpretative methodology. The attempt to discern the intention of the Founders behind a constitutional term which had been stigmatized as ambiguous would necessarily be fuelled to a significant extent by the identification and consultation of relevant historical materials, and it might be that the volumes of the Commonwealth Law Reports would find themselves, in certain circumstances, yielding pride of place to the Convention Debates, and other contemporary sources.

The implications held for the federal balance by an ascendant doctrine of constitutional intentionalism would be fascinating. The basic point to grasp is that the Founding Fathers unquestionably intended that the balance of power in the Australian federation should be considerably more in favour of the States than has come to be the case. ${ }^{108}$ As was

\footnotetext{
10. McHugh, supra, note 38 at 122.

105. See generally, S. Kenny, "Constitutional Fact Ascertainment" (1990) 1 Public Law Review 134.

106. See supra, text accompanying note 21 .

107. See also e.g. Commonwealth, supra, note 14 at 126-27, Mason J. and 220-22, Murphy J.; Koowarta, supra, note 38 at 225. Mason J.; Hematite Petroleum Pty. Ltd., supra, note 73 at 630-32, Mason C.J. and 660-62, Deane J. Similar statements could be made concerning some of the "economic" reasoning contained in decisions conceming section 92: see e.g. Bath v. Halston Holdings Pty. Lid. (1985), 78 A.L.R. 669 at 675-80.
}

108.

See e.g. Craven, supra, note 55 at 81 . 
noted,${ }^{109}$ the overall effect of literalism in this context has been to permit the expansive interpretation of provisions conferring legislative power on the Commonwealth by quarantining such provisions from the (restrictive) subjective intentions which accompanied their making. What is amply demonstrated by the Corporations case is that the injection of these subjective intentions into the interpretative equation can have a significantly confining effect upon words which might otherwise be made to carry a fair burden in support of the expansion of Commonwealth legislative competence. ${ }^{110}$ It is thus probable that a new emphasis upon the actual intentions of the Founders would tend strongly in the direction of confining, and perhaps even winding back, the extent of Commonwealth power.

Correspondingly, intentionalism is not an interpretative approach which offers much to a Court determined to develop constitutional doctrine into new and unexplored areas. Tied as it is to a legal species of historical determinism, intentionalism is a force which is directed towards restricting, rather than enhancing judicial choice. Thus, there would be little room within an intentionalist methodology for such projects as the development of a more or less comprehensive scheme of constitutional guarantees of individual liberties.

As with progressivism, an intentionalist Court would have to face a variety of important issues arising over its choice of interpretative methodology. For a start, intentionalism is unattractive in one important respect: it raises the spectre of Australia's constitutional arrangements being ruled by the "dead hand of the past'."' This is a potent rallying cry, and an intentionalist Court would need to be able to counter such arguments, presumably by reference to some notion of the continuing democratic legitimacy of the constitutional intentions of the Founders. ${ }^{1 / 2}$ In any event, the controversy would be intense.

Another major issue corresponds directly with that confronting a progressivist over the suitability of judges as formulators of policy: if judges are not trained in the art of policy-making, are they necessarily any better educated in the arcane mysteries of history? Arguably, if constitutional interpretation is primarily a matter of history, it would be better left to historians than to lawyers. ${ }^{113}$ This argument leads to the question whether anyone, historian or lawyer, can determine the past intention of a third party, especially in relation to any subject so complex as the meaning to be carried by this or that term of

See supra, text accompanying notes 27-32.

lbid.

See Craven, supra, note 81 at 178-79; in an American context see L. Simon, "The Authority of the Framers of the Constitution: Can Originalist Interpretation Be Justified?" (1985) Califormia Law Review 1482 at 1531-35.

See supra, text accompanying notes 82-85.

Cf. Brest, supra, note 96 at 218-22. 
a century-old constitution. This topic, which has produced a voluminous literature in the United States, ${ }^{114}$ is not pursued here. ${ }^{115}$

The difficulty in spelling out the various questions which a 'progressivist' or an 'intentionalist' Court would need to face is that, at least in the short term, we are unlikely to see the emergence of a Court which neatly fits either of these labels. Rather, what we may expect with reasonable confidence - and arguably already have - is a Court which flirts with elements of both progressivism and intentionalism, without articulating the basis of either, and which jumps rather chaotically from one to the other, and from both to literalism, according to the circumstances surrounding the particular case before it. Thus, in the Corporations case ${ }^{116}$ (and to some extent in Cole v. Whitfield) ${ }^{117}$ we see a Court which is significantly intentionalist in its orientation; in Dams ${ }^{118}$ we may discern progressivist influences; and in a number of cases the old Engineers-style literalism continues unabated. ${ }^{119}$

However deficient the High Court's literalism may have been as a method of constitutional interpretation, it had at least the lonely virtue of general consistency of application. There is a real danger that the dissolution of the literalist hegemony will see a long period of confusion, indecision and imprecision on the Court, during which it will not be possible to say that any interpretative approach holds sway. Perhaps the most profound difficulty to be faced in this swirling mist of competing methodologies is that, at heart, each contains considerably more than a grain of truth to the average Australian constitutional lawyer. Thus, real weight should be given to the plain constitutional text. The interpretation of the Constitution should, wherever possible, advance the current interests of the Australian people. The Court should be faithful to the intentions of the Framers. But none of these approaches in isolation seems to be capable of providing a fully self-sustaining account of the process of constitutional interpretation in Australia, nor of delivering a knock-down blow to objections raised by protagonists of the other methodologies. The most likely result, then, in the absence of any possible reconciliation between these approaches, is one of prevalent conflict and confusion.

\section{THE FUTURE - IS THERE A WAY FORWARD?}

It follows that reconciling these contending interpretative theories would in fact be an extremely difficult task. Nevertheless, if one accepts the suggestion made above that each does represent a desirable end or value in the process of constitutional interpretation, and if one also accepts that without some form of reconciliation the interpretation of the

114

See e.g. Brest, supra, note 96; and see generally T. Eagleton, Literary Theory (1983) 62-88; M. Kelman, A Guide to Critical Legal Studies (1987) 213-23.

115. But see Craven, supra, note 81 at 179.

116. (1990), 64 A.L.J.R. 157.

117. (1988), 165 C.L.R. 360.

118. Commonwealth, supra, note 14.

119. See c.g. Richardson, supra, note 27 at 307, Deane J. 
Australian Constitution will inevitably become an increasingly fragmented and incoherent process, then any attempt at synthesis, however tentative, must be of some value.

Having been unremittingly critical of the High Court's current methodology, the author feels in fairness compelled to suggest the type of synthesis desired. It is in no sense intended in this piece to fully articulate and justify this synthesis, but merely to sketch its chief features in necessarily broad terms. For lack of a better name, it will be referred to as 'contextualism', for reasons that will quickly become apparent. As an interpretative methodology, it would rest on five central propositions.

The first is that in the interpretation of the Australian Constitution, it is indeed the case that the search for the intentions of those who framed the document is paramount. It would seem that this proposition is necessarily contained not only in any theory of intentionalism, but also - fundamentally - in literalism (or at least in Australian literalism). As has been seen, the supremacy of the words under literalism flows primarily from their alleged status as windows into the minds of the Founders. ${ }^{120}$ Moreover, a general acceptance of the necessity to search for the Founders' intent would seem to be unavoidable according to conventional Australian understandings of democratic theory and historical legitimacy. It is the bargain struck by the Founders and embodied in the Constitution that was directly ratified by the Australian people. This bargain, obviously, was a product of the intentions of the Founders, which the words of the Constitution were employed to reflect. In the absence of subsequent constitutional amendment, it continues to comprise the latest authentic expression of the will of the people of Australia on the subject of their nation's constitutional dispositions. ${ }^{21}$

The second proposition is that it nevertheless must be accepted that large portions of the Constitution are ambiguous. Naturally, this ambiguity will more often be found in provisions dealing with broad and complex subjects than with those dealing with procedural machinery and other relatively straightforward topics. Thus, many of the placita of section 51 are classic examples of constitutional ambiguity, being more apt to indicate in general terms a field of legislative capacity than to delineate it with any degree of precision. ${ }^{122}$ The critical question for Australian constitutionalists is, having admitted this ambiguity of the Constitution and rejected the false security offered by ritual applications of Engineers-style concepts of 'natural meaning', how is constitutional ambiguity to be resolved? How is the hidden intention to be uncovered?

This leads to the third proposition. In seeking to draw the intention from an ambiguous provision, the Court is entitled, and indeed obliged as a matter of constitutional duty, to have regard to the full range of materials that are potentially of use in fixing and

\footnotetext{
120. See supra, text accompanying notes 7 and 81-86.

121. See Craven, supra, note 81 at 177-78.

122. For example, section 51(1) (overseas and interstate trade and commerce), section 51(29) (external affairs) and section 5I(38) (virtually unidentifiable, but see Port McDonald Professional Fishermen's Association and Olrich v. South Australia (1989), 63 A.L.J.R. 671).
} 
elucidating that intention. Once it is accepted that the intention is the grail, and that the relevant constitutional language is ambiguous, there can be no excuse for the Court choosing to avert its eyes from sources which may assist it in discerning the intent behind the provision in question. At the very least, such sources would ordinarily include the Convention Debates and the Draft Constitution Bills, but there is no reason why contemporary speeches, ${ }^{123}$ articles, newspapers and even correspondence should not be relevant.

Nevertheless, it would be foolish not to acknowledge that there will inevitably be occasions, probably many occasions, when a consultation of historical materials will produce no clear intention. It may be that there is simply no evidence as to the intention one way or the other, or the available evidence may reflect such a riot of conflicting points of view as to be effectively useless. In such circumstances it would be impossible for the Court to isolate any specific contemporary intention behind the relevant provision, and the question which naturally arises is: where would it go from there?

The fourth proposition seeks to at least partly resolve this dilemma. Where the Court has determined that the constitutional language in question is ambiguous, and where it is unable through a consultation of appropriate materials to isolate with at least a reasonable degree of conviction the contemporary intention behind the provision, the Court should (subject to one qualification which will be advanced presently), adopt that interpretation which seems to it to best match the current interests, needs and values of the Australian people. In so doing, the Court should be explicit about the predicament in which it finds itself. It should state its finding of ambiguity, explain the unhelpful nature of the historical record, and fully articulate the policy considerations which have led it to adopt one interpretation over another. Obviously, it is this limb of contextualism which encapsulates the policy-choice elements of progressivism. It is not proposed that the High Court would be entirely free to act in accordance with its perception of national needs, without any recourse to the basic intentions of the Founders.

Thus, the fifth proposition operates by way of restraint upon the fourth. In determining which interpretation would most closely accord with the values and needs of the Australian people, the High Court should attach great weight to the fundamental constitutional values of the Founders, which emerge not only from a non-technical reading of the constitutional document as a whole, but from an appropriate understanding of the general history of the movement for federation, and the drafting of the Constitution. ${ }^{24}$

Clearly, the concept of 'fundamental constitutional values' is not a precise one, but the identification and application of such values would assist the Court to structure what

123.

124.

To a significant degree, a link could be drawn between such a process and that involved in the present practice of drawing implications from federalism: see e.g. Melbourne Corporation, supra. note 24; Victoria v. Commonwealth (1971), 122 C.L.R. 353; Queensland Electricity Commission v. Commonwealth (1985), 159 C.L.R. 192. 
would otherwise be naked policy choices. To take an obvious example, probably the clearest of the values of the Founders' was a profound belief in strongly co-ordinate federalism, a belief which runs throughout the pages of their printed Debates, and which permeates the Constitution itself. ${ }^{125}$ An application of this value to federal division of power disputes would tend to work so as to resolve such disputes in favour of the States, rather than the Commonwealth. Naturally, there are other basic constitutional values which could be called into play: those relating to parliamentary and responsible government ${ }^{126}$ immediately come to mind. Unquestionably, there would be room for bitter dispute as to the place of particular values within the constitutional conception of the Founders ${ }^{127}$ but there is no system of constitutional interpretation which can entirely banish an element of disputation, and at least the controversies here would consist of arguments over basic constitutional values, rather than battles between competing semantic assertions.

It should be apparent from this brief outline why the term 'contextualism' has been chosen as a name for this interpretative approach. Its essential method is to contextualize the whole process of constitutional interpretation in at least four ways: first, by placing the written document within the context of the actual intent of the Founders; second, by insisting that this constitutional intention be elicited through a consultation of the full historical record; third, by requiring that insoluble textual ambiguity be dealt with by placing the interpretative problem against a background of the general needs and aspirations of the Australian people; and finally, by mandating that even this last step take account of the fundamental contemporary values and conceptions that surrounded the making of the Constitution and the federation which it supports.

It should be equally clear that contextualism contains elements of intentionalism, literalism and progressivism. Obviously, its underlying orientation is one of a moderate intentionalism. Its concession to literalism lies chiefly in the fact that it would concede that an entirely unambiguous text is a conclusive vehicle of intention. Contextualism also leans towards a modified progressivism in accepting the need for policy choice in the absence of compelling indications of contemporary intention, although this tendency is mitigated by the injection of the fundamental contemporary values of the Founders. It is worth noting that a judge minded to embrace such an interpretative approach would be able with reasonable ease to construct for it an impressive, if slightly indirect, lineage in terms of precedent.

Doubtless, such an approach would not appeal to those absolutely committed to one of the other interpretative theories considered in this article, and would thus draw sharp

See Craven, supra, note 55 at 50-53.

The existence of which is prominently recognized in the joint judgment in the Engineers case (1920), 28 C.L.R 129 at 151.

127. those turning upon a concept of "national unity:" see e.g. Hematite Petroleum Pry. Ltd., supra, note 73 at 660 , Deane $\mathrm{J}$. 
criticism. A strong intentionalist would regard it as impossibly soft on the question of the determinative character of Founder's intent, while a progressivist would see it as confining within far too rigid boundaries the Court's ability to make necessary social choices. To a literalist, contextualism's de-emphasis of the certainty of constitutional language, acceptance of extra-textual sources and acknowledgement of a (limited) policy role for the Court would be about equally objectionable. All that can be urged in favour of the interpretative method outlined here is that whatever difficulties of acceptance and application it might face, it does seek to provide a principled and articulated approach to constitutional interpretation, within which is reconciled (so far as is possible) the competing values perceived as being relevant in the construction of the Australian Constitution.

In any event, and whatever the specific deficiencies of contextualism, there can be little doubt that the High Court's present constitutional methodology is increasingly in a state of disarray. As the literalism of Engineers becomes increasingly threadbare, and as the competing influences of progressivism and intentionalism contend to fill the gap, the whole process of constitutional interpretation will tend to become unstable and unpredictable. In the midst of this chaos, one can at least be comforted by the thought that whatever interpretative theory the High Court may eventually come to accept, it could hardly be less intellectually appealing than literalism. 